\title{
ANOTHER INDIAN SPECIES OF HOMOPORUS THOMSON (HYMENOPTERA: CHALCIDOIDEA: PTEROMALIDAE)
}

\author{
P.M. Sureshan ${ }^{1}$ and T.C. Narendran ${ }^{2}$ \\ ${ }^{1}$ Zoological Survey of India, Western Ghats Field Research Station, Calicut, Kerala 673002, India. \\ ${ }^{2}$ Systematic Entomology Laboratory, Department of Zoology, University of Calicut, Kerala 673635, India.
}

\begin{abstract}
The Indian species of Homoporus Thomson has been reviewed. After the recent description of a new species Homoporus gladiatus from India, another new species, Homoporus acuminatus sp. nov. is described in this paper. A key to Indian species of Homoporus is provided.
\end{abstract}

\section{Key words}

Pteromalidae, Homoporus, Homoporus acuminatus sp. nov., Homoporus gladiatus, key

\begin{tabular}{lr}
\multicolumn{2}{c}{ Abbreviations } \\
BMNH - The Natural History Museum, London & F1-F4 - Funicular segments 1 to 4 \\
MV - Marginal vein & OOL - Ocell-ocular distance \\
PMV - Postmarginal vein & POL - Post-ocellar distance \\
SMV - Submarginal vein & STV - Stigmal vein \\
T1- First gastral tergite & ZSI - Zoological Survey of India
\end{tabular}

\section{Introduction}

Homoporus Thomson is well known from the western Palaearctic and Nearctic regions (Graham, 1969; Boucek \& Heydon, 1997). From the Oriental region the genus is poorly known. Boucek et al. (1979) reported an undetermined species of Homoporus from Pakistan and, Sureshan and Narendran (2000) described a species, $H$. gladiatus from India. In this paper, a new species, $H$. acuminatus sp. nov. from India is described along with a key to the Indian species.

\section{Homoporus acuminatus sp. nov.}

(Figs. 1-2)

\section{Material examined}

Holotype: Female, iv.1989, Calicut University Campus, Malappuram District, Kerala, Coll. P.M. Sureshan (ZSI, Calicut). Paratypes: One female, same data as that of holotype; One female, 6.v.1989, Anappady, Parambikulam Wildlife Sanctuary, Kerala, Coll. P.M. Sureshan; Six females, ii.1987, 3.xi.1986, v.1988, v.1989,

vii.1989, viii.1989, Calicut University Campus, Kerala, Coll. T.C. Narendran and party; One female, 26.ii.1988, Neeleswaram, Kasaragod District, Kerala, Coll. P.M. Sureshan (ZSI, Calicut).

\section{Distribution \\ India: Calicut in Kerala.}

\section{Etymology}

Species name pertains to the acuminate nature of antenna.

\section{Diagnostic features}

Female: Length 1.3-2.3mm (Holotype 2.3mm). Head and mesosoma black; gaster yellowish brown; antennae testaceous with basal half of scape white; coxae brown, remainder of legs testaceous; fore coxae and femora darker; tegulae brown; wings hyaline; veins pale brown.

Head: Finely engraved reticulate with sparse white hairs; clypeus finely striate, striae reaching little below lower margin of eyes; anterior margin of clypeus weakly emarginate. In dorsal view head width1.3x width of mesoscutum and $2.1 \mathrm{x}$ length and in front view width $1.3 x$ height; vertex almost smooth, narrow; temple length half of eye length; POL 1.2x OOL; malar sulcus 
weakly indicated; malar space length $0.5 x$ eye height; eyes seperated $1.4 \mathrm{x}$ their height. Antennae inserted below middle of face, almost level with lower margin of eyes; scape not reaching median ocellus, length $0.9 x$ eye height; pedicel plus flagellum length $0.8 x$ head width; funicular segments gradually widening towards the tip; club acuminate with a sharp terminal stylus.

Mesosoma: Figure 1. Strongly arched in profile with sparse white hairs; pronotum finely reticulate, anterior margin of collar finely ridged mainly on sides. Mesoscutum with broad meshed reticulation, width $2.5 x$ length. Scutellum medially $1.1 x$ as long as mesoscutum, similarly sculptured as mesoscutum. Propodeum (Fig. 2) medially $0.6 \mathrm{x}$ as long as scutellum, very finely reticulate, nucha small, little raised, spiracles short, elongatedly oval; callus with thin long hairs, not dense. Mesopleuron and metapleuron almost smooth. Fore wing (Fig. 1) with basal part almost bare, discal pubescence short but dense, costal cell hairy on the upper half, almost completely towards the distal tip. Relative lengths: SMV 24, MV 12.5, PMV 11.5, STV 6.
Gaster: (Fig. 2) Ovate, smooth, dorsally collapsing; petiole small, transverse; gaster little longer than head plus mesosoma combined (1.1x); hind margin of $\mathrm{T} 1$ medially produced and slightly incised in the middle.

\section{Remarks}

In the key to British species of Homoporus by Graham (1969) this species keyed out to the couplet 12 . It resembles $H$. fulviventris (Walker) in having antennae inserted slightly above level of ventral margin of eyes, combined length of pedicel plus flagellum distinctly less than width of head and club with a terminal stylus. One of us (PMS) examined the type of $H$. fulviventris (Walker) (=Pteromalus fulviventris Walker in BMNH. $H$. acuminatus sp. nov. differs from $H$. fulviventris in having antennae uniformly testaceous with F1-F4 distinctly longer than wide, scutellum strongly convex in profile, head finely reticulate and gaster more brownish and body not slender (in fulviventris F1 almost quadrate, other funicular segments quadrate to slightly transverse, scape and pedicel blackish brown, scutellum less convex, head moderately reticulate, gaster more yellowish and body slender.).

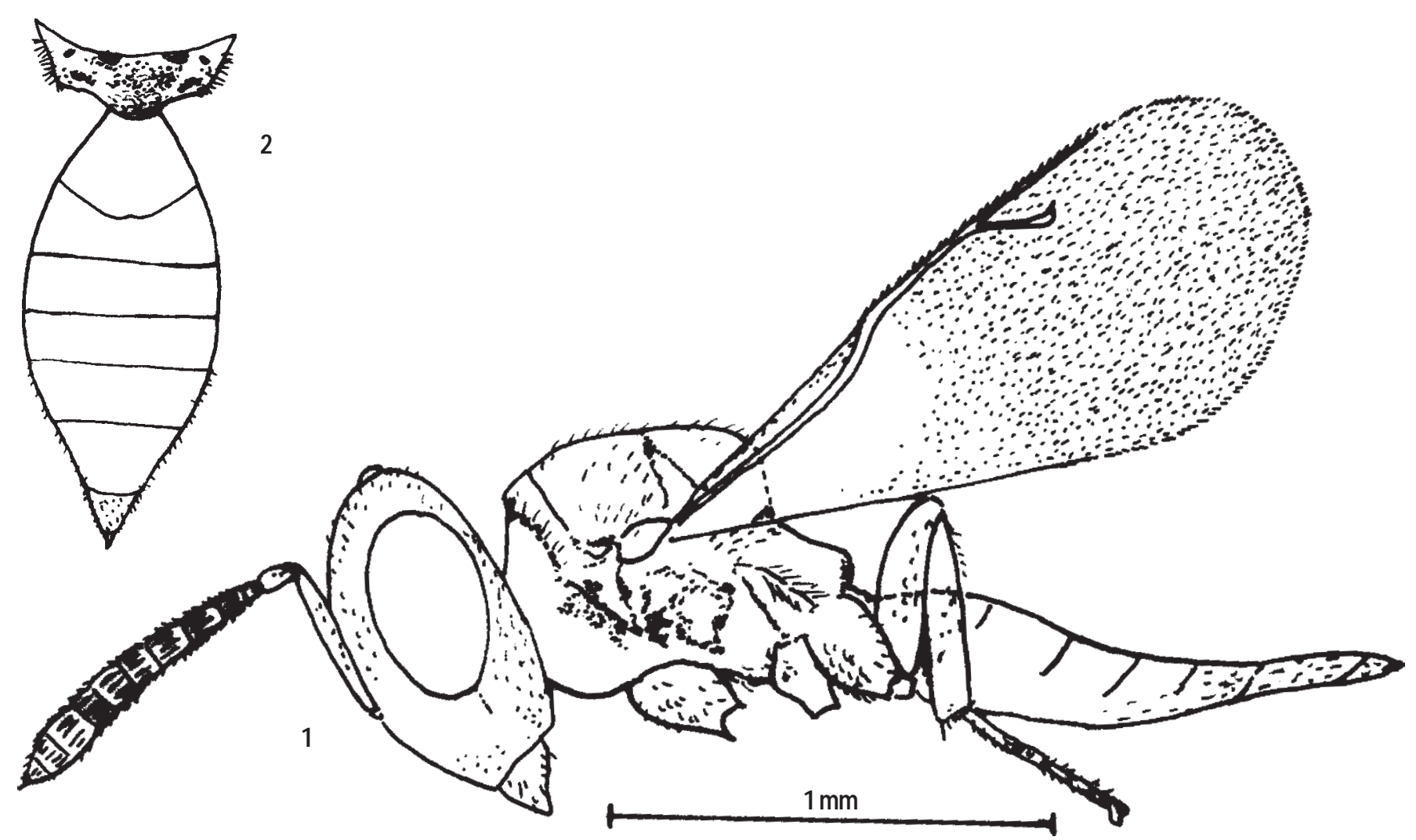

Figures 1-2. Homoporus acuminatus sp. nov. (Female). 1. Body in profile; 2. Propodeum and gaster in dorsal view. 




$1 \mathrm{~mm}$

\section{Homoporus gladiatus Sureshan and Narendran}

(Figs. 3-5)

Homoporus gladiatus Sureshan and Narendran (2000), 10 females, 18 males, India: Kerala (ZSI, Calicut).

\section{Distribution}

India: Kerala.

\section{Diagnostic features}

Female: Length 2.5-2. 8mm. Head and mesosoma black without metallic reflection. Gaster pale brownish yellow with two dark brown lines dorso-laterally on either sides, tip also brown. Head finely reticulate, clypeus and lower face striated, lower margin of clypeus with a deep notch in the middle (Fig. 4). Antennae inserted in the middle of face, scape reaching beyond median ocellus; club acute, terminal stylus not prominent.

Mesosoma: (Fig. 3) Moderately arched in profile, reticulate punctate. Propodeum finely reticulate, median carina indicated towards the distal part; nucha convex. Fore wing with PMV distinclty shorter than MV.

Gaster: (Fig. 3) Elongate, ovate, dorsally collapsing with a short petiole; hind margin of T1 almost straight.

Male: (Fig. 5) Length 1.9-2. 6mm. Resembles female except for the antenna inserted high up on face with funicular segments elongate and densely pubescent and gaster short with an yellow spot sub-apically on dorsal part.

\section{Acknowledgements}

The first author is grateful to the Director, Zoological Survey of India, Calcutta and the Officer-in-charge, ZSI, Calicut for providing facilities and encouragement. We are also grateful to Dr. John S. Noyes and Miss. Suzanne Lewis, BMNH, London for kindly arranging the loan of type specimens for the study. 


\section{References}

Boucek, Z. and S.L. Heydon (1997). Family Pteromalidae pp. 541692. In Gibson, G.A.P. et.al. (Eds.), 1997. Annotated keys to the genera of Nearctic Chalcidoidea (Hymenoptera). NRC Research press, Ottawa, Ontario, Canada. 794 pp.

Boucek, Z., B.R. Subba Rao and S.I. Farooqi (1979). A preliminary review of Pteromalidae (Hymenoptera) of India and adjacent countries.
Oriental Insects 12(4): 433-466.

Graham, M.W.R. de V. (1969). The Pteromalidae of northwestern Europe (Hymenoptera: Chalcidoidea). Bulletin of the British Museum of Natural History - Entomology Supplement 16: 1-908.

Sureshan, P.M. and T.C. Narendran (2000). Pteromalidae (Chalcidoidea: Hymenoptera) from India with the description of a new species. Entomon 25(2): 117-128.

\section{Key to the Indian species of Homoporus Thomson}

1. Antennae slender (Fig. 3) inserted distinctly above lower margin of eyes, club with apex acute, terminal stylus not prominent; gaster with hind margin of T1 straight; fifth tarsal segment of mid and hind legs swollen (Fig. 3)

H. gladiatus Sureshan and Narendran

2. Antennae not slender (Fig. 1), inserted almost level with lower margin of eyes, club acuminate with terminal stylus prominent; gaster with hind margin of T1 medially produced and slightly incised (Fig. 2); tarsal segments not swollen as above

\section{ZOOS' PRINT JOURNAL gratefully acknowledges the following external editors for their contribution to the improvement of the Journal publications in 2000.}

Prof. T.N.Ananthakrishnan

Chennai, Tamil Nadu

Dr. Chellam Balasundaram

Thiruchirapally, Tamil Nadu

Dr. B.K. Biswas

Kolkota, West Bengal

Dr. Apurba Chakraborty

Guwahati, Assam

Dr. S.K. Gupta

Kolkota, West Bengal

Dr. Mohammed Hayat

Aligarh, Uttar Pradesh

\section{Dr. Sultan Ismail}

Chennai, Tamil Nadu

Dr. J.M. Julka

Solan, Himachal Pradesh

T.R. Mitra

Calcutta, West Bengal

Dr.D. Mohanasundaram

Coimbatore, Tamil Nadu

Mr.P.O. Nameer

Trissur, Kerala

Dr. Md. Jafer Palot

Hyderabad, Andhra Pradesh
Dr. A.H. Parulekar

Dona Paula, Goa

Dr. N. Sethuramalingam

Mysore, Karnataka

Dr. M.S. Shishodia

Kolkota, West Bengal

Mr. C. Srinivasulu

Hyderabad, Andhra Pradesh

Dr. Tembhare

Nagpur, Maharashtra

Dr. V. Vasu

Patiala, Punjab 